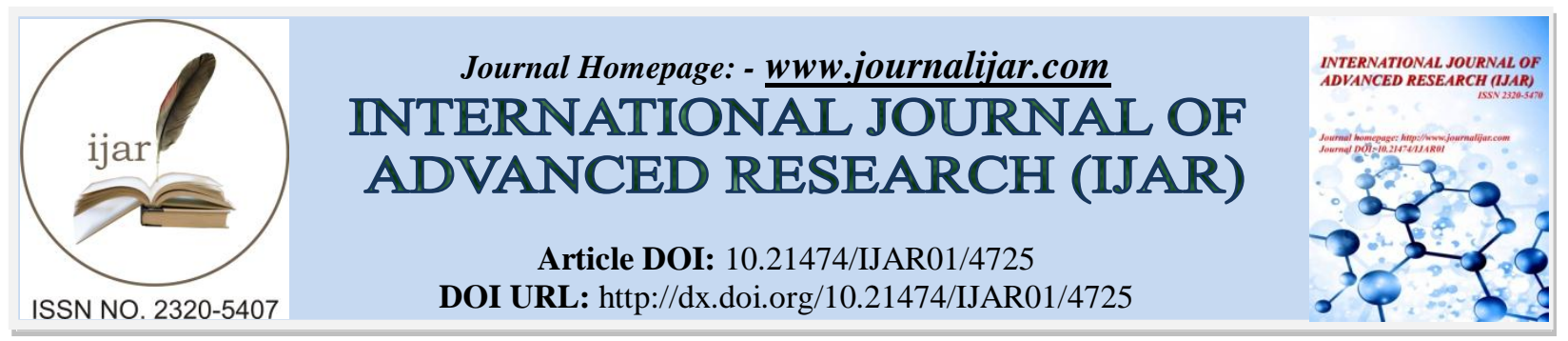

RESEARCH ARTICLE

\title{
MICROWAVE ASSISTED SYNTHESIS OF SOME SUBSTITUTED 2-PYRAZOLINE - A GREEN APPROACH.
}

\author{
"Rashmi Sharma ${ }^{1}$ and Dr. Ajay M. Chaturvedi ${ }^{2}$. \\ 1. Department of Chemistry, P.M.B. Gujarati Science College, Indore (M.P.). \\ 2. Department of Chemistry, Govt. Madhav Science P.G. College, Ujjain (M.P.).
}

\section{Manuscript Info}

Manuscript History

Received: 4 May 2017

Final Accepted: 6 June 2017

Published: July 2017

Key words:-

Microwave synthesis, Chalcones,

Thiosemicarbazide, 2-Pyrazoline,

Antibacterial activity.

\begin{abstract}
Microwave assisted synthesis of chalcones under solvent-free conditions resulted in a "green chemistry" procedure for the preparation of 2-pyrazoline derivatives in very good yields. 1-Thiocarbamoyl-3,5diphenyl-2-pyrazoline was synthesized by the MWI of a mixture of corresponding chalcone, thiosemicarbazide and $\mathrm{NaOH}$ in ethanol in modified domestic microwave oven and characterized on the basis of elemental analysis, molecular weight determination and spectral data like ${ }^{1} \mathrm{H}-\mathrm{NMR}$, IR. These compounds were screened for their antibacterial activity against gram positive and gram negative bacteria.
\end{abstract}

Copy Right, IJAR, 2017,. All rights reserved.

\section{Introduction:-}

Over the years various innovative methods have been devised to speed up the chemical reactions. In these environmentally conscious days the development of technology is directed towards eco-friendly methods. The usage of microwave energy to accelerate the organic reactions is of increasing interest and offers several advantages over conventional heating techniques. ${ }^{1}$ Synthesis of the molecules which normally requires a long time can be achieved conveniently and rapidly in microwave oven. Solvent free condition is especially suitable for microwave activation. Thus the use of microwave energy for the synthesis of organic compounds forms a part of green chemistry.

The partially reduced form of pyrazole is named as pyrazoline or 4,5-dihydropyrazole or 2-pyrazoline. Pyrazolines are nitrogen containing 5-membered heterocyclic compound. It has only one endo-cyclic double bond and is basic in nature ${ }^{1}$. The pyrazoline function is quite stable and has inspired chemists to utilize this stable fragment in bioactive moieties to synthesize new compounds possessing biological activities. Keeping in the view of advantages of microwave heating, in the present investigation we have carried out the synthesis of some $\alpha, \beta$-unsaturated ketones (chalcones), which undergo a subsequent cyclization reaction with thiosemicarbazide affording 2-pyrazolines ${ }^{1}$. They have been found to possess antifungal, anticonvulsant, antidepressant, anti-inflammatory, antibacterial, anticancer, antioxidant, antiviral, antiamoebic and antituberculosis activities. ${ }^{2-16}$ This reaction is generally carried out in presence of base like $\mathrm{NaOH}$ or $\mathrm{KOH}$ which are harmful, toxic and polluting. Therefore in the present investigation we have used anhydrous $\mathrm{K}_{2} \mathrm{CO}_{3}$ as the condensing agent which is cheap, non- toxic and easy to use. Furthermore, the reaction can be easily carried out under solvent free condition under microwave irradiation, so as to minimize the pollution. All the prepared compounds were screened for their antimicrobial activities. 


\section{Experimental work:-}

\section{Material and methods:-}

Domestic microwave oven Electrolux of $2.54 \mathrm{GHz}$ modified for 'reflux organic synthesis' was used within 100-300 watt level, for MWI method. Microwave safe 'borosil' glass apparatus were used for the synthesis in microwave oven. All the compounds were synthesized by using analytical grade chemicals of Across Organics, Fisher Scientific, Qualigens, CDH and Merck. Melting points of the synthesized compounds are uncorrected and were determined in sealed capillary tubes in BESTO melting point apparatus. All the synthesized compounds were characterized by melting point determination, elemental analysis, FTIR, ${ }^{1} \mathrm{H}-\mathrm{NMR}$ and LCMS spectral studies.

\section{Synthesis of Substituted Pyrazolines:-}

Substituted pyrazoline was synthesized in two steps by MWI method. The general method for the synthesis of substituted pyrazoline is as follows:

\section{Step I: Synthesis of substituted chalcones:-}

In the first step an equimolar quantity of various substituted acetophenones and substituted aromatic aldehydes were thoroughly mixed with anhydrous $\mathrm{K}_{2} \mathrm{CO}_{3}$ to form a thick paste. The paste was air dried and the residual mass was subjected to microwave irradiation for 3-5 minutes. After completion of the reaction the contents were dissolved in ethanol. Inorganic material was filtered off and filtrate after concentration in vacuum was left overnight to afford the desired chalcones in $80-90 \%$ yield. ${ }^{17-22}$ The analytical and physical data of the synthesized compounds (1a, 1b, 1d, 1e) is summarized in Table -1

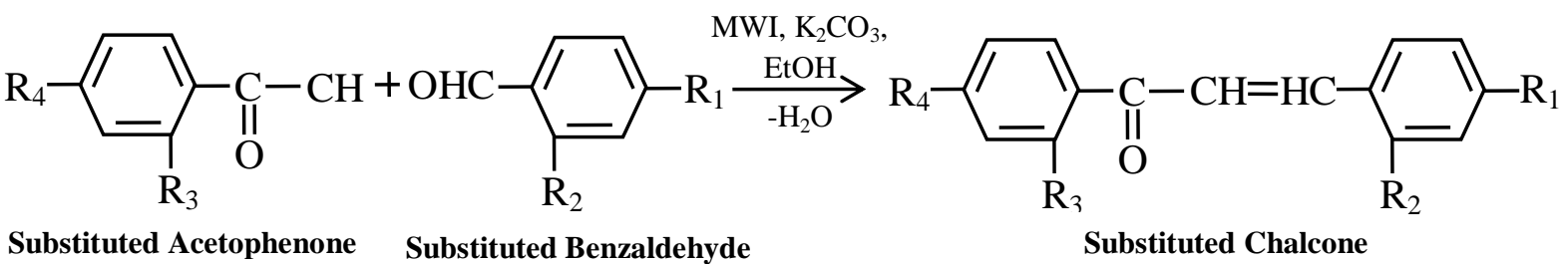

\section{Scheme - I}

\section{Step II: Synthesis of substituted pyrazolines:-}

In the second step, synthesized chalcones were treated with thiosemicarbazide, and various substituted pyrazolines were synthesized. All the reagents were taken in equimolar ratio $(0.01 \mathrm{~mole})$ in ethanol and their mixture solution was microwave irradiated for 10-15 minutes cautiously at low temperature in modified microwave oven. ${ }^{23-25}$ The analytical and physical data of the synthesized compound (2a, $\mathbf{2 b}, \mathbf{2 d}, \mathbf{2 e})$ is summarized in Table - $\mathbf{2}$

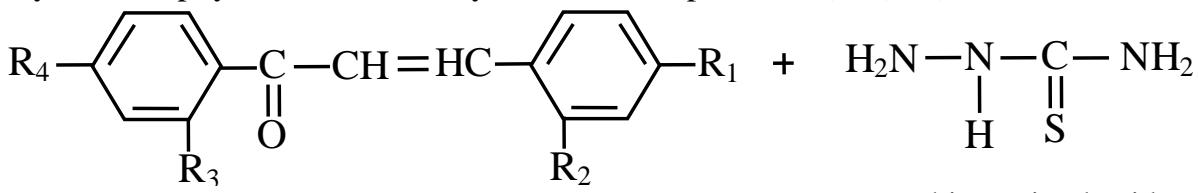

Substituted Chalcone

Thiosemicarbazide

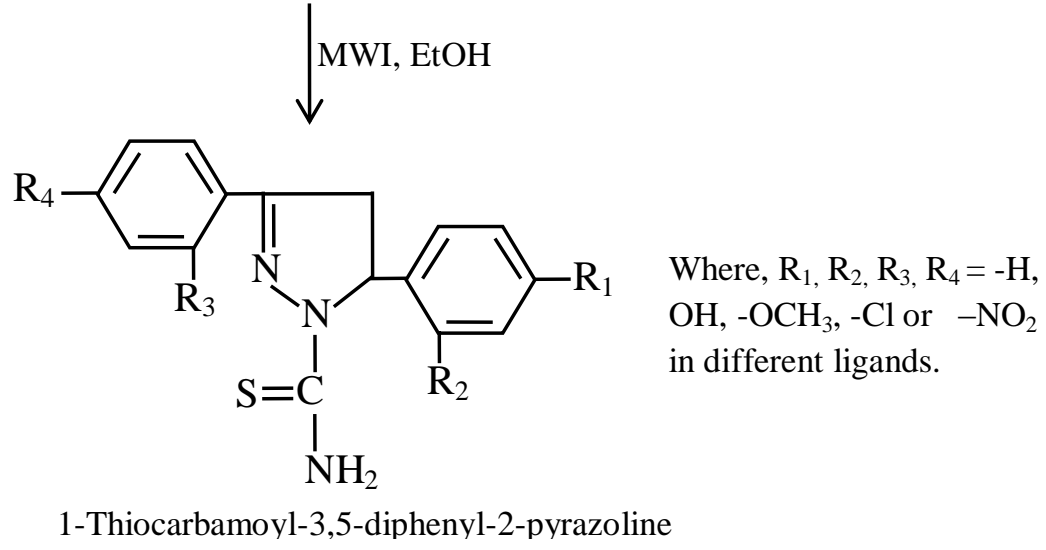

Scheme - II 
Experimental Data of Compounds:-

Table-1:- Analytical and Physical data of synthesized Chalcones:

\begin{tabular}{|c|c|c|c|c|c|c|}
\hline Product & $\begin{array}{c}\text { Molecular } \\
\text { formula }\end{array}$ & $\begin{array}{c}\text { Molecular weight in } \\
\text { g/mol }\end{array}$ & Colour & $\begin{array}{c}\text { M.P. } \\
\left({ }^{\circ} \mathbf{C}\right)\end{array}$ & $\begin{array}{c}\text { Yield } \\
(\boldsymbol{\%})\end{array}$ & $\begin{array}{c}\text { Time required } \\
(\mathbf{m i n} .)\end{array}$ \\
\hline 1a & $\mathrm{C}_{15} \mathrm{H}_{12} \mathrm{O}$ & 208.25 & Yellow & 56 & 82 & $4-6$ \\
\hline 1b & $\mathrm{C}_{15} \mathrm{H}_{11} \mathrm{ClO}_{2}$ & 257.50 & Yellow & 131 & 90 & $4-6$ \\
\hline 1d & $\mathrm{C}_{15} \mathrm{H}_{10} \mathrm{Cl}_{2} \mathrm{O}$ & 277.14 & Pale Yellow & 110 & 90 & $4-6$ \\
\hline 1e & $\mathrm{C}_{16} \mathrm{H}_{14} \mathrm{O}_{3}$ & 254.00 & Yellow & 169 & 92 & $4-6$ \\
\hline
\end{tabular}

Table-2:- Analytical and Physical data of synthesized Pyrazolines

\begin{tabular}{|c|c|c|c|c|c|c|c|c|c|c|}
\hline \multirow{2}{*}{$\begin{array}{c}\text { Produ } \\
\text { ct }\end{array}$} & \multirow{2}{*}{$\begin{array}{c}\text { Molecular } \\
\text { formula }\end{array}$} & $\begin{array}{c}\text { M.W. Found } \\
\left(\begin{array}{c}\text { calculated) } \\
\text { g/mol }\end{array}\right.\end{array}$ & Colour & \multirow{2}{*}{$\begin{array}{c}\text { M.P. } \\
\left({ }^{\circ} \mathbf{C}\right)\end{array}$} & \multirow{2}{*}{$\begin{array}{c}\text { Yield } \\
(\boldsymbol{\%})\end{array}$} & \multicolumn{4}{|c|}{ Elemental analysis found (calculated) } \\
\hline 2a & $\mathrm{C}_{16} \mathrm{H}_{15} \mathrm{SN}_{3}$ & $281.37(280.3)$ & $\begin{array}{c}\text { Pale } \\
\text { yellow }\end{array}$ & 165 & 55 & $\begin{array}{c}68.3 \\
(68.6)\end{array}$ & $\begin{array}{c}5.37 \\
(5.8)\end{array}$ & $\begin{array}{c}14.93 \\
(15.2)\end{array}$ & $\begin{array}{c}11.4 \\
(11.8)\end{array}$ & - \\
\hline $\mathbf{2 b}$ & $\mathrm{C}_{16} \mathrm{H}_{14} \mathrm{SN}_{3} \mathrm{ClO}$ & $313.81(312.6)$ & Yellow & 226 & 89 & $\begin{array}{c}57.91 \\
(58.1)\end{array}$ & $\begin{array}{c}4.25 \\
(4.6)\end{array}$ & $\begin{array}{c}12.66 \\
(12.7)\end{array}$ & $\begin{array}{c}9.66 \\
(10.2)\end{array}$ & $\begin{array}{c}10.68 \\
(10.8)\end{array}$ \\
\hline $\mathbf{2 d}$ & $\mathrm{C}_{16} \mathrm{H}_{13} \mathrm{SN}_{3} \mathrm{Cl}_{2}$ & $350.26(349.2)$ & Yellow & 142 & 68 & $\begin{array}{c}54.86 \\
(54.9)\end{array}$ & $\begin{array}{c}3.74 \\
(3.9)\end{array}$ & $\begin{array}{c}12.0 \\
(12.8)\end{array}$ & $\begin{array}{c}9.15 \\
(9.4)\end{array}$ & $\begin{array}{c}20.24 \\
(20.6)\end{array}$ \\
\hline $\mathbf{2 e}$ & $\mathrm{C}_{17} \mathrm{H}_{17} \mathrm{SN}_{3} \mathrm{O}_{2}$ & $327.40(326.6)$ & $\begin{array}{c}\text { Creamy } \\
\text { yellow }\end{array}$ & 227 & 51 & $\begin{array}{c}62.36 \\
(62.5)\end{array}$ & $\begin{array}{c}5.23 \\
(5.4)\end{array}$ & $\begin{array}{c}12.83 \\
(12.9)\end{array}$ & $\begin{array}{c}9.79 \\
(10.2)\end{array}$ & - \\
\hline
\end{tabular}

Spectral Data of Compounds:-

(2a) 1-Thiocarbamoyl-3,5-diphenyl-2-pyrazoline:

IR v $\left(\mathrm{cm}^{-1}\right): 1582(\mathrm{C}=\mathrm{N}), 1071(\mathrm{C}-\mathrm{N}), 827(\mathrm{~N}-\mathrm{N}), 1564 \&$ 3000-3042 (Ar-nu), 1147(C=S); ${ }^{1} \mathrm{H}-\mathrm{NMR} \delta(\mathrm{ppm})$ : 3.3-3.1 $\left(\mathrm{C}_{4}-\mathrm{CH}_{2}\right), 4.0\left(\mathrm{C}_{5}-\mathrm{CH}\right), 7.7-6.6(\mathrm{Ar}-\mathrm{H})$.

(2b) 1-Thiocarbamoyl-3-(2'-hydroxyphenyl)-5-(4-chlorophenyl)-2-pyrazoline:

IR v $\left(\mathrm{cm}^{-1}\right): 1584(\mathrm{C}=\mathrm{N}), 1073(\mathrm{C}-\mathrm{N}), 825(\mathrm{~N}-\mathrm{N}), 1590 \& 3000-3045(\mathrm{Ar}-\mathrm{nu}), 1170(\mathrm{C}=\mathrm{S}), 3080-2990(\mathrm{Ar}-\mathrm{OH})$; ${ }^{1} \mathrm{H}-\mathrm{NMR} \delta(\mathrm{ppm}): 3.3-2.9\left(\mathrm{C}_{4}-\mathrm{CH}_{2}\right), 6.3\left(\mathrm{C}_{5}-\mathrm{CH}\right), 7.4-6.3(\mathrm{Ar}-\mathrm{H}), 7.4(\mathrm{Ar}-\mathrm{OH})$.

(2d) 1-Thiocarbamoyl-3-(4'-chlorophenyl)-5-(4-chlorophenyl)-2-pyrazoline:

IR v $\left(\mathrm{cm}^{-1}\right): 1578(\mathrm{C}=\mathrm{N}), 1082(\mathrm{C}-\mathrm{N}), 814(\mathrm{~N}-\mathrm{N}), 1599 \& 2995-3070(\mathrm{Ar}-\mathrm{nu}), 1183(\mathrm{C}=\mathrm{S}), 773(\mathrm{C}-\mathrm{Cl}) ;{ }^{1} \mathrm{H}-\mathrm{NMR}$ $\delta(\mathrm{ppm}): 3.4-2.5\left(\mathrm{C}_{4}-\mathrm{CH}_{2}\right), 6.1\left(\mathrm{C}_{5}-\mathrm{CH}\right), 8.1-7.2(\mathrm{Ar}-\mathrm{H})$.

(2e) 1-Thiocarbamoyl-3-(4'-hydroxyphenyl)-5-(4-methoxyphenyl)-2-pyrazoline:

IR v $\left(\mathrm{cm}^{-1}\right): 1586(\mathrm{C}=\mathrm{N}), 1076(\mathrm{C}-\mathrm{N}), 813(\mathrm{~N}-\mathrm{N}), 1603 \& 3025-3074(\mathrm{Ar}-\mathrm{nu}), 449(\mathrm{C}=\mathrm{S}), 3095-2990(\mathrm{Ar}-\mathrm{OH}) ;{ }^{1} \mathrm{H}-$ NMR $\delta(\mathrm{ppm}): 3.5-2.9\left(\mathrm{C}_{4}-\mathrm{CH}_{2}\right), 5.9\left(\mathrm{C}_{5}-\mathrm{CH}\right), 8.3-7.5(\mathrm{Ar}-\mathrm{H})$, 10.9-9.8 ( $\left.\mathrm{Ar}-\mathrm{OH}\right)$.

Antimicrobial Activity:-

The biocidal activity of synthesized substituted pyrazolines was studied in order to prove their utility. For this purpose, some bacteria's like Staphylococcus aureus MRSA (gram positive bacteria), Pseudomonas spp. (gram positive bacteria), Escherichia coli (gram negative bacteria), Bacillus cereus (gram negative bacteria) were cultured on Mueller- Hinton agar plates and by using block well diffusion method, then the effect of synthesized pyrazolines (2a, 2b, 2c, and 2d) were screened. All the synthesized compounds exhibited moderate to excellent antibacterial activities. Some of them were found to be more effective in comparison to standard drugs (Amikacin and Gentamicin). Antimicrobial activity of the synthesized compounds is represented in Table 3. 
Table 3:- Antimicrobial activity of substituted 1-Thiocarbamoyl-3,5-diphenyl-2-pyrazoline

\begin{tabular}{|c|c|c|c|c|c|c|c|c|}
\hline \multirow{4}{*}{ Compound } & \multicolumn{8}{|c|}{ Zone of Inhibition in $\mathbf{~ m m}$} \\
\hline & \multicolumn{8}{|c|}{ Bacteria } \\
\hline & \multicolumn{2}{|c|}{ S. Aureus } & \multicolumn{2}{|c|}{ E. Coli } & \multicolumn{2}{|c|}{ Pseudomonas } & \multicolumn{2}{|c|}{ Bacillus } \\
\hline & Zone size & Activity & $\begin{array}{l}\text { Zone } \\
\text { size }\end{array}$ & Activity & Zone size & Activity & Zone size & Activity \\
\hline $2 a$ & 05 & $\mathbf{R}$ & 11 & I & 06 & $\mathbf{R}$ & 06 & $\mathbf{R}$ \\
\hline $2 b$ & 13 & $\mathbf{I}$ & 22 & $\mathbf{E}$ & 08 & $\mathbf{R}$ & 11 & $\mathbf{I}$ \\
\hline $2 d$ & 08 & $\mathbf{R}$ & 06 & $\mathbf{R}$ & 20 & $\mathbf{E}$ & 08 & $\mathbf{R}$ \\
\hline $2 e$ & 20 & $\mathbf{E}$ & 13 & I & 14 & I & 20 & $\mathbf{E}$ \\
\hline $\begin{array}{c}\text { Std. Drug } \\
\text { (Amk and } \\
\text { Gen) }\end{array}$ & $\begin{array}{l}05 \\
06\end{array}$ & $\begin{array}{l}\mathbf{R} \\
\mathbf{R}\end{array}$ & $\begin{array}{l}12 \\
12\end{array}$ & $\begin{array}{l}\text { I } \\
\text { I }\end{array}$ & $\begin{array}{l}12 \\
14\end{array}$ & $\begin{array}{l}\text { I } \\
\text { I }\end{array}$ & $\begin{array}{l}16 \\
18\end{array}$ & $\begin{array}{l}\mathbf{S} \\
\mathbf{S}\end{array}$ \\
\hline
\end{tabular}

\section{Results and Discussion:-}

In this paper, microwave assisted synthesis of chalcones (1a, 1b, 1d and 1e) has been reported by the reaction of substituted acetophenone and substituted benzaldehydes in the presence of anhydrous $\mathrm{K}_{2} \mathrm{CO}_{3}$. These chalcones were treated with thiosemicarbazide under microwave irradiation to yield 2-pyrazolines (2a, 2b, 2d and 2e), in 10-15 minutes. The synthetic procedure for preparation of title compounds is given in reaction scheme I and II. The assigned structure and molecular formula of the newly synthesized compounds (2a, $\mathbf{2} \mathbf{b}, \mathbf{2 d}$ and $\mathbf{2 e}$ ) were confirmed and supported by ${ }^{1} \mathrm{H}-\mathrm{NMR}$ and IR data as well as elemental analysis, which was in full agreement with proposed structures. All the compounds were screened in vitro for their antibacterial potential by block well diffusion assay against selected bacteria. The results of antibacterial activities expressed in terms of zone of inhibition are reported in Table 3. All the synthesized compounds have shown significant to excellent activity against E. coli, S. aureaus, Bacillus and Pseudomonas.

\section{Conclusion:-}

In summary, this work demonstrates a rapid, efficient and environment friendly method for the synthesis of these compounds (substituted chalcones and 2-pyrazolines) under microwave irradiation. The results obtained confirm that the use of microwave has shown the advantages like high yields, relatively short reaction times, low cost, simple experimental and isolation procedures, and finally, it is in agreement with the green chemistry protocols. The results of antimicrobial studies of synthesized compounds revealed that they possess moderate to potent antibacterial activities against the tested gram positive and gram negative microorganisms. The data reported in this paper may be helpful as a guide for the medicinal chemists, who are working in this area.

\section{References:-}

1. Khan S. A., Asiri A. M., Kumar S. and Sharma K., (2014), Green synthesis, antibacterial activity andcomputational study of pyrazoline and pyrimidine derivatives from 3-(3, 4-dimethoxy-phenyl-1-(2, 5dimethyl-thiophen-3-yl)-proenone, Eur. J. Chem., 5(1), 85-90.

2. Dhindsa K. S., Dudeja M., Malhotra R. and Gupta M. P., (1993), Synthesis and characterization of Co (II), $\mathrm{Ni}(\mathrm{II})$ and Co (II) complexes of 1-acetyl-5-aryl-3-(substituted thienyl)-2-pyrazolines and their microbiocidal activity, Indian J. Chem., 32A, 975-979.

3. Sangwan N. K., Singh N. and Dhindsa K. S. (2000), Synthesis and fungitoxic activity of 5-aryl-1-formyl-4, 5dihydro-3-(2-hydroxyphenyl)-1H-pyrazoles and their complexes, Pest. Manag. Sci., 56, 284-288.

4. Ozdemir Z., Calis U., Bilgin A. A., Kandilci H. B. and Gumusel B., (2007), Synthesis and studies on antidepressant and anticonvulsant activities of some 3-(2-furyl)-pyrazoline derivatives, Eur.J. Med. Chem., 42(3), 373-379.

5. Abdel-Aziz M., El-Din A., Abuo-Rahma G. and Hassan A. A., (2009), Synthesis of novel pyrazole derivatives and evaluation of their antidepressant and anticonvulsant actvities, Eur. J. Med. Chem., 44, 3480-3487.

6. Kumar A., Srivastava V. K. and Rani P., (2004) Synthesis and anti-inflammatory activity of heterocyclic indole derivatives, Eur. J. Med. Chem., , 39, 449-452.

7. Al-Jibori M. N., Al-Bayatiand S. M. and Rasheed A. M., (2013), Coordination modes of a new ligand derived from pyrazoline with $\mathrm{Cr}(\mathrm{III}), \mathrm{Mn}(\mathrm{II}), \mathrm{Co}(\mathrm{II}), \mathrm{Ni}(\mathrm{II}), \mathrm{Cu}(\mathrm{II})$ and $\mathrm{Zn}(\mathrm{II})$ metal ions; Synthesis, identification and biological studies, Chem. Mat. Res., 3, 1-12. 
8. El-Wahab Z. H. A., Faheim A. A. and Mashaly M. M., (2005), Synthesis and characterization of cobat(II), cerium (III) and dioxouranium (VI) complexes of 2, 3-dimethyl -1- phenyl-4-salicylidene-3-pyrazolin-5-one mixed ligand complexes, pyrolytic products and biological activities, Chem. Pap., 59, 25-36.

9. Abu-Surrah A. S., Safieh K. A., Ayoub M. T., Qaroush A. K., Abu-Mahtheieh A. M., Ahmad I. M. and Abdalla M. Y., (2010), New palladium (II) complexes bearing pyrazole-basal schiff base ligands; Synthesis, characterization and cytotoxicity, Eur. J. Med. Chem., 45, 471-475.

10. Saleem K., Wani W. A., Haque A., Lone M. N., Ali I., Ming-Fa H. and Jairajpuri M. A., (2013), Synthesis, DNA binding, hemolysis assays and anticancer studies of copper (II), nickel (II) and iron(III) complexes of a pyrazoline-based ligand, Future Med. Chem., 5, 135-146.

11. Dasary K., Lavania A., Yadav M. and Anand A. V. K., (2013), Synthesis, characterization and study of antioxidant activities of some new pyrazoline derivatives containing Isatin moiety, Int. J. Res. Engin. Sci., (IJRES), 1(7), 08-13.

12. El-Sabbagh O. I., Baraka M. M., Ibrahim S. M., Pannecouque P., Anderi G., Snoeck R., Balzarini J. and Rashad A. A., (2009), Synthesis and antiviral activity of new pyrazole and thiazole derivatives, Eur. J. Med. Chem., 44, 3746-3753.

13. Budakoti A., Abid M. and Azam A., (2006), Synthesis and antiamoebic activity of new 1-N-substituted thiocarbamoyl-3, 5-diphenyl-2-pyrazoline derivatives and their Pd (II) complexes. Eur.J. Med. Chem., 41, 6370.

14. Singh P., Negi J. S., Rawat M. S. M. and Pant G. J. N., (2013), Synthesis, antiamoebic activity and thermal study of copper complexes of 1-formyl-2-pyrazolines., J. Therm. Anal. Calorim., III, 549-552.

15. Ali M. A., Shaharyar M. and Siddiqui A. A., Synthesis, structural activity relationship and antitubercular activity of novel pyrazolines derivatives, Eur. J. Med. Chem., 42(2), 268-275.

16. Coutinho E. C., Khunt R. K., Khedkar V. M., Chawda R. S., Chauhan N. A. and Parikh A. R., (2007), Synthesis, antitubercular evaluation and 3D-QSAR study of N-phenyl-3-(4-fluorophenyl)-4-substituted pyrazole derivatives, Bioorg. Med. Chem. Lett., 2012, 22(6), 666-678.

17. C. R. Strauss, (2009), Aust. J. Chem., 62(1), 3-15.

18. Varma R. S.,et. al.(2006), Top. Curr. Chem., 266, 199-231.

19. Shailendra Mandge, et.al.(2007),Synthesis and Characterization of Some Chalcone Derivatives, Trends in Applied Sciences Research, 2, 52-56.

20. Bhavana Sharma et.al.(2008), Colour Reactions of Chalcones and their Mechanism (A Review), Oriental Journal of Chemistry, Vol.24(1), 289-294.

21. M.R. Jaypal et.al.(2010), Anhydrous $\mathrm{K}_{2} \mathrm{CO}_{3}$ as Catalyst for Synthesis of Chalcones under Microwave Irradiation, Journal of Pharmaceutical Sciences and Research, Vol. 2(10), 644-647.

22. M.M.H. Bhuiyan et.al.(2011), Microwave-assisted Efficient Synthesis of Chalcones as Prob for Antimicrobial Activities, Chemistry Journal, Vol. 1, 21-28.

23. Vikas Tiwari et.al.(2011), Microwave Assisted Improved Synthesis of Chalcones under Microwave Irradiation and their Antibacterial Activity, J. Chem. Bio. Phy. Sci., Vol.1, 22-27.

24. R. Revathi et.al.(2013), Microwave Assisted Synthesis and Biological Activity of Certain 4-Hydroxy Chalcones, Pharmacophore, Vol.4(2), 59-69.

25. Davood Azafifar et.al.(2003), Microvave Assisted Synthesis of Some 3,5-Arylated 2-Pyrazoline, Molecules, Vol. 8, 642-648. 